\title{
Research on the path of Cultivating College Students' entrepreneurial ability from the perspective of the Communist Youth League
}

\author{
Zhi-quan $\mathrm{An}^{1}$, Peng Zhang ${ }^{2} *$, Zi-wen Wang ${ }^{2}$ \\ ${ }^{1}$ Beihua University, China \\ ${ }^{2}$ Beihua University, College of physical education, Longteng innovation and entrepreneurship education base \\ *Corresponding author
}

Keywords: Communist Youth League students, Entrepreneurial ability.

\begin{abstract}
College Students' entrepreneurial activities are not only the need to solve the employment predicament and maintain social stability, but also the need to train technical talents and realize the national innovation strategy. The Communist Youth League is an important position for colleges and universities to educate, manage and serve college students. The Communist Youth League should give full play to its advantages and resources and play an important role in the cultivation of College Students' entrepreneurial ability.
\end{abstract}

\section{Introduction}

China is moving from the employment era to the entrepreneurial era, and Youth Innovation and entrepreneurship has become an important driving force for the future economic development of the country. The Communist Youth League as a mass organization, should give full play to its own comparative advantage, play a positive role in cultivating college students' entrepreneurial ability, enhance students' entrepreneurial ability.

The advantages of the Communist Youth League in the training of College Students' entrepreneurial ability

\section{Organizational advantages}

The sacred mission given by the party and the state to the Communist Youth League is to train and reserve forces for the future of the party and the country. Over the years, the Communist Youth League in promoting college students' theoretical study and social practice, volunteer service, scientific and technological innovation work, the accumulation of a large number of social resources, to establish a good relationship of cooperation with enterprises, become the students to understand the society and expand the social ability and the indispensable organization ${ }^{[1]}$. In the school, almost all of the young students are members of the Communist Youth League, League organization, the Youth League branch in the Communist Youth League and other forms in schools, faculties and students at all levels.

\section{Platform advantages}

As the implementation of the main organizations expand students' second class quality, was a rare resource in various countries, local universities and other aspects and strong support, provides a unique platform ${ }^{[2]}$ for the Communist Youth League organizations to better serve the students' entrepreneurial ability cultivation. The Communist Youth League Organization creative design quality development system of college students, in the talent of ideological education, social practice and innovation of science and technology and other important training work, building accords with the law of education by the students love working mechanism, design and carry out a 
series of prominent theme, profound meaning, lively and vivid quality development activities, to attract the majority of young students to actively participate in. Strengthen innovation consciousness, enhance practical ability, actively cultivate the proper quality and ability for future entrepreneurship.

\section{Emotional advantage}

The Communist Youth League and college students have a profound origin of emotion, the organization system construction, to achieve full coverage of college students, in the work mechanism construction, identify the law of growth of young students, in the work carrier design, to meet the psychological characteristics of young people. All these make life in the organization of young students have a strong sense of belonging and happiness, to ensure that the organization of the Communist Youth League can play well attract role in young students, is able to unite and lead the students to study diligently, the healthy growth of ${ }^{[3]}$.

\section{The Communist Youth League training college students entrepreneurial ability approach}

\section{To improve the League organization's own entrepreneurial guidance ability.}

First, college and university cadres should correctly use the national entrepreneurship policy, and provide guidance for the students' entrepreneurship through the country's macro entrepreneurship situation and its development trends. Next, the group cadres should gradually understand and master the professional norms and professional knowledge, and grasp the necessary job hunting skills, so as to provide practical guidance for graduates. The three is to strengthen the understanding of the employment situation and research efforts, and strengthen the forward-looking and practical work of students' career guidance. Four is to identify the position in the work, grasp the principle of fishing, to help students clear their own employment direction.

\section{Strengthen ideological education and guide students to change their careers.}

The current college students' Outlook on employment, the expectation of employment and the deviation from social reality are one of the reasons for the difficulty of College Students' employment. Mass organizations should play in the ideological and political education of the traditional advantages, through lectures, seminars, theme activities, league, debate, speech contest, social practice, college entrepreneurs forum, to guide students to establish flexible employment, employment career "concept of employment, to encourage students to the grassroots, to the motherland where it is needed to make contributions to the west, and establish an" entrepreneurship "thought ${ }^{[4]}$.

\section{To build entrepreneurial practice platform to improve the practical ability of College students.}

Entrepreneurship practice is the concrete way to realize entrepreneurship education, and it is also an effective way to cultivate college students' entrepreneurial awareness and entrepreneurial ability. Therefore, it is necessary to provide entrepreneurial practice platform for college students and encourage entrepreneurial practice. The League organization should strengthen the communication and cooperation with the functional departments inside and outside the school, integrate the resources both inside and outside the school, provide students with venues to try their own business, and turn the entrepreneurial awareness into entrepreneurial practice. This can not only give the students relevant perceptual knowledge, and even experience the opportunity of entrepreneurship, but also turn the entrepreneurial education into entrepreneurial practice and test its effectiveness. In the actual process of entrepreneurship, through cooperation and communication with the community, to enable students to undergo training in the course of socialization, in business practice to understand the social, social cognition, edify sentiment, in business practice to enhance the quality, enhance the sense of social responsibility and a sense of belonging, to improve the students' ability to adapt to society better. The tree to the facade of grass-roots employment, the concept of entrepreneurship. 


\section{To play the role of the Communist Youth League culture, and create a good atmosphere for entrepreneurial campus}

The Communist Youth League should actively carry forward the educational function of campus culture, and create a favorable environment for entrepreneurial campus culture. First, through the organization of "science and Technology Cultural Festival", "campus simulation recruitment meeting" and other campus cultural activities, so that innovation and entrepreneurship awareness, innovation and entrepreneurship has become an important content of campus culture and campus spirit. Two, through career education, to guide students to establish innovation, entrepreneurship, value goals. So that students can start from the social needs, combined with their own characteristics, cultivate students' innovative spirit and entrepreneurial awareness, and establish innovative and entrepreneurial value goals. Three is to strive to promote innovation and entrepreneurship culture. As a part of campus culture, the entrepreneurial culture of universities is conducive to the cultivation and exploration of entrepreneurial talents. Through fostering the interest and quality of young students' innovation and entrepreneurship, the Communist Youth League will stimulate students' innovative spirit, enhance their awareness of entrepreneurship, and help them to enhance their confidence in innovation and entrepreneurship.

\section{To give full play to the resource advantages of the Communist Youth League organizations and build a platform for college students to start an undertaking.}

League organization has rich human resources and social activities positions, and through contacts with all sectors of society to help students master entrepreneurial skills. Through inviting experienced entrepreneurs, entrepreneurs and officials from related fields to lectures and dialogues in the school, the students will be provided with entrepreneurial experience and skills. Regular organization of students to business visits, broaden the horizons of students, stimulate students' entrepreneurial motivation and entrepreneurial needs. Hold a business plan competition, so that students can get the experience of analog entrepreneurship, exercise team spirit, communication and organizational management capabilities. To strengthen the relationship between schools and society and enterprises, to win the support of enterprises for entrepreneurship education, to create opportunities for students to imitate business practice, and to enrich students' entrepreneurial learning and practice.

\section{The full implementation of the quality development plan for college students, improve the overall quality and core competitiveness}

To improve the comprehensive quality of college students and enhance their core competitiveness is the basic way to solve the problem of entrepreneurship. To this end, the Communist Youth League organizations should be based on the overall situation of College Students' quality development plan, promote the students non intelligence ability. On the one hand, we should strengthen the cultivation of interpersonal skills. Through the second classroom activities organized a variety of healthy, strengthen, young students and school teachers and students of social extensive exchanges and contact between different individuals, promote interpersonal skills and teamwork ability. On the other hand, it is necessary to improve the social adaptability of College students. We should extensively carry out large-scale social practice activities with distinctive subjects and distinctive features, and establish social practice bases in well-known enterprises, scientific research institutes and regional governments, so as to improve their adaptability and practical ability.

\section{Conclusion}

In a word, college students' entrepreneurship is a systematic project and requires the joint efforts of the whole society. A role to improve college students' entrepreneurial ability is not only the college group work, is also a kind of attitude, is a kind of ability, is also a kind of style, is the new responsibilities of college group organization at present and in the future for a long period. The 
Communist Youth League organizations should combine their own characteristics, bringing the advantages, integrate the advantages of resources, to carry out a variety of ideological education and practice activities, improve the comprehensive quality of students, cultivating students' core competence, to create a new situation of College Students' entrepreneurship promotion work.

\section{Acknowledgements}

This research was financially supported by National school youth league research project of the Central School Department of China Communist Youth League (2017LX043)

\section{References}

[1] Wang Wei, Cao Yingnan. Reflections on College Students' entrepreneurship education carried out by the Communist Youth League organizations, Journal of Inner Mongolia Radio \& TV University, vol. 10, pp. 99-101, 2008.

[2] Cao Jinli, Thinking of College Communist Youth League organizations promoting college students' employment and Entrepreneurship, The Science Education Article Collects, vol. 7, pp. 69, 2009.

[3] Wang Fei, Yao Guanxin. On Improving College Students' Ability to Recognize Opportunities in Starting an Undertaking, journal of national academy of education administration, vol. 8, pp. $57-60,2014$.

[4] Zheng Yanxia. Investigation and analysis of College Students' entrepreneurial readiness: taking universities in Beijing as an example, Journal of Tonghua Normal University, vol. 34, pp. 105-108,2013. 